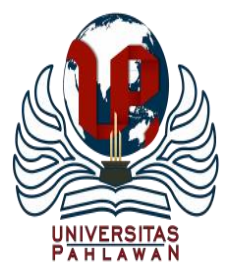

Edukatif : Jurnal Ilmu Pendidikan Volume 3 Nomor 2 Tahun 2021 Halm 421 - 428 EDUKATIF: JURNAL ILMU PENDIDIKAN

Research \& Learning in Education

https:/ledukatif.org/index.php/edukatif/index

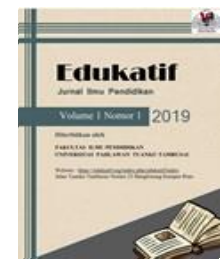

\title{
Learning Methods Of Consilidated Statement in Advanced Accounting
}

\author{
Asepma Hygi Prihastuti ${ }^{\circledR}$, Sonia Sischa Eka Putri², Saipul Al Sukri ${ }^{3}$ \\ Sekolah Tinggi Ilmu Ekonomi, Persada Bunda ${ }^{1}$ \\ Universitas Islam Negeri Sultan Syarif Kasim Riau ${ }^{2,3}$ \\ E-mail : asepma@ stiepersadabunda.ac.id ${ }^{1}$, Sonia.sischa@uin-suska.ac.id $^{2} \underline{\text { saipul.alsukri@gmail.com }}^{3}$
}

\begin{abstract}
Abstrak
Penelitian ini dikembangkan mengingat kesulitan mahasiswa dalam memahami keterkaitan antar sub bab laporan keuangan konsolidasi pada Mata kuliah akuntansi lanjutan. Ini mengakibatkan rendahnya motivasi dan hasil belajar Mahasiswa. Penelitian ini bertujuan untuk menganalisis pengaruh penggunaan metode Mind Mapping dan Problem Based Learning terhadap motivasi dan hasil belajar pada mahasiswa D3 Akuntansi STIE Persada Bunda. Penggunaan metode pembelajaran dimaksud memang sudah umum dan sering di jumpai pada prodi pendidikan dan mata pelajaran tingkat sekolah. Namun sangat jarang dalam kegiatan pembelajaran di bangku perkuliahan. Penelitian ini menggunakan uji beda analisis motivasi dan hasil belajar siswa antara kelompok eksperimen dan kelompok kontrol yang diolah menggunakan metode Paired sample test dengan SPSS versi 21. Hasil analisis uji beda motivasi belajar menggunakan uji-t diperoleh nilai t -14,692 dengan sig $=0,000$. Artinya penggunaan Mind Mapping dan Problem Based Learning memiliki pengaruh yang lebih baik terhadap motivasi belajar siswa dibandingkan dengan metode konvensional. Dan hasil uji beda analisis hasil belajar diperoleh nilai t-test sebesar -16,533 dengan sig 0,000. Artinya terdapat pengaruh positif penggunaan metode Mind Mapping dan Problem Based Learning terhadap hasil belajar siswa secara meyakinkan. Hasil penelitian ini bisa dijadikan masukan bagi para dosen agar bisa terus berinovasi dalam menerapkan metode dalam proses belajar mengajar, sehingga kemampuan mahasiswa dapat ditingkatkan.
\end{abstract}

Kata Kunci: Laporan Keuangan Konsolidasi, Mind Mapping, Problem Based Learning.

\begin{abstract}
This research is based on the students' difficulty in understanding the concept of interrelationship between sub chapters of the consolidated financial statement in advanced accounting, resulting in low motivation and learning outcome. This might be because the lecturer still uses conventional methods. This research aims to analyze the effect of the use of Mind Mapping and Problem Based Learning methods on motivation and learning outcomes of students in D3 Accounting STIE Persada Bunda. The use of this learning method is indeed common in education programs and school-level subjects. However, it is rarely applied in learning activities in university.This research uses a comparison test analysis of students' motivation and learning outcomes between the experimental group and the control group which was processed using the Paired sample test method with SPSS version 21. The result of the comparison test analysis of learning motivation using $t$-test obtained $t$ value of -14,692 with sig =0,000. It means that the use of Mind Mapping and Problem Based Learning has a better effect on students' learning motivation than conventional methods. And the result of the comparison test analysis of learning outcome, the t-test obtained $t$ value of -16,533 with a sig of 0,000. It means that there is a positive effect on the use of Mind Mapping and Problem Based Learning methods on students' learning outcomes convincingly. The results of this research can be used as input for lecturers so that they can continue to innovate in applying teaching and learning methods, so that students' abilities can be improved.
\end{abstract}

Keywords: Consolidated Financial Statement, Mind Mapping, Problem Based Learning.

Copyright (c) 2021 Asepma Hygi Prihastuti, Sonia Sischa Eka Putri, Saipul Al Sukri $\triangle$ Corresponding author

Email : asepma@stiepersadabunda.ac.id

DOI : https://doi.org/10.31004/edukatif.v3i2.303

ISSN 2656-8063 (Media Cetak)

ISSN 2656-8071 (Media Online)

Edukatif : Jurnal Ilmu Pendidikan Vol 3 No 2 Tahun 2021 p-ISSN 2656-8063 e-ISSN 2656-8071 


\section{INTRODUCTION}

A paradigm shift in the world of education is something that is widely discussed today. One of the things that underlie these changes are the demands of 21 st century learning. Critical thinking skills, communication skills, problem solving, collaboration, information literacy, innovation and creation are some of the important and relevant skills a student should have. Besides the four pillars of life which include learning to know, learning to do, learning to be and learning to live together (Delors, 2013); (Sari, 2020). In addition, according to Benyamin Bloom (Bennett \& Bloom, 1979) learning ability includes at least three important things, namely: 1) cognitive abilities. 2) effective ability. 3) Psychomotor Ability.

The duties and roles of lecturers in learning also experience a shift. Lecturers who are the spearhead of education are required to have more skills than previous lessons. Lecturers are directly responsible for improving the quality of education through improving the quality of learning (Azrai \& Refirman, 2013); (A. Suryanda, Sartono, \& Sa'Diyah, 2019); (Ade Suryanda, Putri Azrai, \& Julita, 2019). The role of Lecturers in the 21st century has shifted from being a "knowledge planter" to becoming a mentor, discussion director and measuring student learning progress ("Ideas 21st Century Educ.," 2017).

In real practice in the field, there are several obstacles faced by lecturers when implementing classroom learning, one of which is about learning methods. Various teaching methods can be developed by lecturers. Teaching materials can also be found in printed books, e-books and others. Even with technological developments now teachers have room to utilize existing technology as a basis for learning resources (Ferliyati, Kurniati, \& Suryanda, 2014); (Komala, Suryanda, \& Lismana, 2018); (Ade Suryanda, Rusdi, \& Kusumawati, 2018).

Even though technology in the digital era is developing very rapidly, the role of lecturers and educational staff will still be needed. As a professional, lecturers must have at least 4 competencies, namely professional competence, pedagogic competence, social competence and personal competence. With regard to pedagogical competence, apart from being required to understand the theory of learning and lecturers are also required to be proficient in the application of learning. One of the skills that lecturers must have is the skill in developing learning resources for their students.

This research is based on the difficulty students of the D3 Accounting STIE Persada Bunda in understanding the concept interrelationship between the sub chapters of the consolidated financial statement in advanced financial accounting courses, so that the impact of students understanding of the material is low and resulting in low student learning outcomes. This might also be caused by the lecturer learning method which still uses conventional methods. The learning process uses conventional methods has several shortcomings, likely students become passive, the learning process is boring, students are sleepy, there is an element of compulsion to listen, as a result conventional learning is not able to develop student abilities optimally.

The results of previous research show that the use of mind mapping methods can encourage students to think synergistically, sharpen their memories and perform imagination through association (Syahidah, 2015). Whereas the Problem Based Learning learning model in the Intermediate Financial Accounting subject can increase accounting competence and increase student motivation in accounting learning until 29.43\% (Herliani \& Sibarani, 2017); (Parasamya \& Wahyuni, 2017). This research aims to improve student motivation and learning outcomes in the Consolidated Financial Statements subject, analyze the effect of the use of Mind Mapping and Problem Based Learning methods on student motivation and learning outcomes in D3 Accounting students at STIE Persada Bunda Pekanbaru.

The subject of this research is students who took advanced financial accounting courses at STIE Persada Bunda 2018/2019 as many as 21 peoples. The research was conducted in 2 cycles with the title 
Consolidation in Fully Owned Subsidiaries given lectures using the Mind Mapping method using the MindManager Pro 6 application as a helper application and Problem Based Learning (PBL). On the other hand in the same class with relatively the same material, namely Consolidation in Subsidiaries Owned by Less than Full Ownership. Previously, lectures were given using conventional methods with the material Consolidated Entities and Consolidated Financial Statements, before action research was conducted.

\section{METHODS}

Research Method describes research plan or research design, location and research participants, data collection technique and data technique used for analysis. This research uses Classroom Action Research (CAR). The four components in the Mind Mapping and Problem Based Learning method are using 4 stages as follows: plan, action, observation, and reflection. These four components are referred to as a cycle of learning activities.

Application of Classroom Action Research (CAR) when planning, which is making Syllabus and Semester Learning Plans (RPS), preparing supporting learning tools and media, preparing test questions, preparing observation sheets to see students skills and skills in presentation and practice, and compile a questionnaire to determine the level of student motivation for learning activities, and completeness criteria (minimum value). Next is the action phase, at this stage the researcher will apply the Mind Mapping and Problem Based Learning learning methods using the facilities and media that have been prepared beforehand. Then, the next stage is the observation phase, where at this stage the research collaborator will make an observation of the teaching and learning process in class and record all learning activities which use Mind Mapping learning methods and Problem Based Learning. The last is the reflection phase, in which at this stage the researchers and collaborators reflect and evaluate the implementation of the use of Mind Mapping and Problem Based Learning methods in advanced financial accounting courses to understand the concepts in the Consolidated Material in Fully Owned Subsidiaries and Consolidation in Subsidiaries Holding Less than Full Ownership.

The details of the activities of each stage of CAR are as follows: 1) The planning stage. At this stage, researchers conducted activities in preparing the completeness of learning tools, such as: preparation of Semester Learning Plans (RPS), books, Mind Mapping applications and Problem Based Learning related to learning methods, and observers. 2) Implementation Phase (action). At this stage, researchers conducted activities that are divided into three parts, namely as follows. Preliminary activities; in this section researchers conducted physical and psychological preparation activities, apperception, and provide motivation. Core activities; in this section include: Lecturers convey competencies to be achieved;The lecturer divides students into several groups, each group consisting of 5-6 students; Instructing students to install the MindManager Pro 6 application on their laptops, then simulate how to use it; The lecturer presents the material on Consolidation in a Fully Owned Subsidiary and Consolidation in Subsidiaries Holding Less than Full Ownership by making a mind map (Mind Mapping) using the MindManager Pro 6 application as a helper application for making Mind Mapping; Lecturers provide case questions as an implementation of the Problem Based Learning (PBL) method; Students discuss with their respective groups, then make Problem Mapping as Problem Solving from the problem cases given by making Mind Mapping using the MindManager Pro 6 application; After finishing, the group representatives are asked to present the results of the discussion of answers to the questions given; and The lecturer clarifies the correct answers. Closing activities; in this section the researcher conducted the activity: summarizing the core of the material discussed, the problem and the solution to the case given. 3) Observation stage; At this stage, to assess the level of learning motivation students after learning, a questionnaire will be distributed. Meanwhile, the learning outcomes will be calculated from the posttest 
conducted. 4) Reflection stage; At this stage a meeting between the observer and the researcher finishes teaching to evaluate, analyze, and discuss the results of observations.

This research was conducted on students of the Department of Accounting STIE Persada Bunda Pekanbaru, Academic Year 2018/2019 who attended Advanced Financial Accounting lectures at STIE Persada Bunda Pekanbaru, located on Jl. Diponegoro No. 42 Pekanbaru-Riau. Respondents were 21 students. The instrument in data collection uses: test, field note, observation checklist, and questionnaire. Students will be asked to answer a number of questions after giving the Consolidation material to the Fully Owned Subsidiary and the Consolidation of the Subsidiary Owning Less Than Full Ownership with Mind Mapping learning methods and the provision of cases based on Problem Based Learning. It aims to measure the extent of increased motivation and student learning outcomes in understanding the material that has been given. After that, researchers will distribute questionnaires to students to measure the level of student motivation to learn Mind Mapping and Problem Based Learning methods that have been done.

To answering the problem statement, the data are analyzed using frequency distribution analysis in the form of tables and line graphs, as follows:

Analysis of frequency distribution using tables; with the formula:

$$
\mathrm{P}=\underline{\mathrm{F}} \times 100 \%
$$

$\mathrm{N}$

In assessing student motivation, researchers used a questionnaire with 9 item questions that were distributed to students after completing lectures. From the results of the learning motivation questionnaire. Motivation achievements will be measured using the size of the categories as in the following table:

Table 1 Student Learning Motivation Assessment Table

\begin{tabular}{ccc}
\hline No. & Range score & Category \\
\hline 1 & $>75-100$ & Very High \\
2 & $>50-75$ & High \\
3 & $>25-50$ & Low \\
4 & $<25$ & Very Low \\
\hline \multicolumn{2}{c}{ Sources: Assessment Table STIE Persada Bunda }
\end{tabular}

Meanwhile, to assess student learning outcomes, researchers analyzed student test results by counting the number of correct answers and calculating the final value of each student so that it would be seen an increase in value above 65 which is a minimum value. This value is the minimum value in Advanced Financial Accounting lectures.

Table 2 Table Assessment of Student Learning Outcomes

\begin{tabular}{ccc}
\hline Range score & Category & $\begin{array}{c}\text { Gra } \\
\text { de }\end{array}$ \\
\hline $80-100$ & Very Good & $\mathrm{A}$ \\
\hline $65-79$ & Good & $\mathrm{B}$ \\
\hline $55-64$ & Enough & $\mathrm{C}$ \\
\hline$<55$ & Less & $\mathrm{D}$ \\
\hline Sources: Assessment Table STIE Persada Bunda
\end{tabular}

In analyzing the differences in learning motivation and student learning outcomes between the experimental group and the control group it was processed using the Paired sample test method with the help 
of SPSS version 21. In conducting the different tests the paired sample test method was used because the control group and the experimental group were carried out to the same class namely the Accounting class B1 at STIE Persada Bunda. What is meant by an experimental class is a class whose learning method uses the Mind Mapping and Problem Based Learning method, while the control class is a class with Conventional Methods.

\section{RESULTS AND DISCUSSION}

Different test findings that learning motivation and student learning outcomes were carried out between the experimental group (given lectures using the Mind Mapping and Problem Based Learning method) with the control group (lectured using conventional methods, such as: lecture method, and powerpoint). Paired sample test is used in the different test method because the control group and the experimental group are conducted to the same class, namely the Accounting class B1 at STIE Persada Bunda.

In this research process is as follows: 1) Students are given lectures on the material Consolidated Entities and Consolidated Financial Statements using conventional methods (as a control group). 2) Students are given lectures on Consolidated Material in a Fully Owned Subsidiary and Consolidation in a Fully Owned Subsidiary by using Mind Mapping and Problem Based Learning methods (as an experimental group). 3) In the two class groups (the experimental group and the control group) at the end of the lecture, they were given a posttest and filled out the learning motivation questionnaire. 4) Different tests (a) learning motivation, and (b) student learning outcomes, such as the following:

The results of the analysis of differences in student learning motivation between the experimental group and the control group were processed using the Paired sample test method with the help of SPSS version 21, the results are as in the following table.

Tabel 3. Mean, SD, dan Std Error Mean Paired Samples Statistics

\begin{tabular}{llcccc}
\hline & & Mean & N & Std. Deviation & Std. Error Mean \\
\hline Pair & Kont-Motv_Konvensional & 57.4076 & 21 & 8.66623 & 1.89113 \\
1 & Eksp-Motv_MM-PBL & 70.1062 & 21 & 5.83528 & 1.27336 \\
\hline
\end{tabular}

Source: Data Processed

Based on Table 3 above shows that the average student learning motivation given lectures using the Mind Mapping and Problem Based Learning methods is higher than using the Conventional Method (70.11 > 57.41). This shows that the use of the Mind Mapping Method and Problem Based Learning is better than the conventional method in increasing the motivation to learn accounting students at STIE Persada Bunda Accounting. Furthermore, to strengthen that the increase in student motivation from 57.41 to 70.11 was caused by the use of the Mind Mapping Method and Problem Based Learning, a different t-test was carried out with the following results:

Table 4. Different Tests of Learning Motivation between Experiment Groups and Control Groups.

\begin{tabular}{|c|c|c|c|c|c|c|c|c|}
\hline \multicolumn{9}{|c|}{ Paired Samples Test } \\
\hline & \multicolumn{5}{|c|}{ Paired Differences } & \multirow{3}{*}{$\mathrm{T}$} & \multirow{3}{*}{ df } & \multirow{3}{*}{ Sig. } \\
\hline & \multirow[t]{2}{*}{ Mean } & \multirow{2}{*}{$\begin{array}{c}\text { Std. } \\
\text { Deviation }\end{array}$} & \multirow{2}{*}{$\begin{array}{c}\text { Std. } \\
\text { Error } \\
\text { Mean }\end{array}$} & \multicolumn{2}{|c|}{$\begin{array}{l}\text { 95\% Confidence Interval } \\
\text { of the Difference }\end{array}$} & & & \\
\hline & & & & Lower & Upper & & & \\
\hline $\begin{array}{l}\text { Kont } \\
\text { Motv_Konvensional } \\
\text { Eksp-Motv_MM-PBL }\end{array}$ & -12.69 & 3.96 & .864 & -14.50 & -10.89 & $-\overline{14.69}$ & 20 & .000 \\
\hline
\end{tabular}


426 Learning Methods Of Consilidated Statement in Advanced Accounting - Asepma Hygi Prihastuti, Sonia Sischa Eka Putri, Saipul Al Sukri

DOI: https://doi.org/10.31004/edukatif.v3i2.303

Sources: Data Processed

From the results of the analysis of different tests about learning motivation using t-tests obtained $t$ value of $-14,692$ with $\operatorname{sig}=0,000$. With a sig of $0,000<0.05$ (tolerance of $5 \%$ ), it means that the use of Mind Mapping and Problem Based Learning learning methods has a positive influence on student motivation in a convincing way or in other words the use of Mind Mapping Method and Problem Based Learning has an influence on learning motivation better students than using conventional methods. The results of this study are in line with (Herliani \& Sibarani, 2017) where motivation and student learning outcomes increase through PBL (Problem Based Learning) learning techniques.

The results of the different test analysis of student learning outcomes between the experimental group and the control group were processed using the Paired Sample Test method with the help of SPSS version 21, the results are as in the following table:

Tabel 5. Mean, SD, dan Std Error Mean Paired Samples Statistics

\begin{tabular}{clcccc}
\hline & & Mean & N & Std. Deviation & Std. Error Mean \\
\hline \multirow{2}{*}{ Pair 1 } & Kont-HB_Konvensional & 58.2381 & 21 & 12.80588 & 2.79447 \\
\cline { 2 - 6 } & Eksp-HB_MM-PBL & 77.8571 & 21 & 12.28428 & 2.68065 \\
\hline \multirow{2}{*}{ Sources: Data Processed } & & & &
\end{tabular}

Based on Table 5 above shows that the average student learning outcomes given lectures using Mind Mapping and Problem Based Learning methods are higher than using Conventional Methods (77.86 > 58.24). This shows that the use of Mind Mapping Method and Problem Based Learning is better than conventional methods in improving student learning outcomes at STIE Persada Bunda Accounting Furthermore to strengthen that the increase in student learning outcomes from 58.24 to 77.86 caused by the use of the Mind Mapping Method and Problem Based Learning, a different test (t-test) was conducted with the following results:

Table 6. Different Tests in Learning Outcomes between the Experimental Group and the Control Group

\section{Paired Samples Test}

\begin{tabular}{|c|c|c|c|c|c|c|c|c|}
\hline & \multicolumn{5}{|c|}{ Paired Differences } & \multirow{3}{*}{$\mathrm{T}$} & \multirow{3}{*}{$\begin{array}{l}D \\
\mathrm{f}\end{array}$} & \multirow{3}{*}{$\begin{array}{l}\text { Sig. } \\
(2- \\
\text { tailed })\end{array}$} \\
\hline & \multirow[t]{2}{*}{ Mean } & \multirow{2}{*}{$\begin{array}{c}\text { Std. } \\
\text { Deviatio } \\
\text { n }\end{array}$} & \multirow{2}{*}{$\begin{array}{l}\text { Std. } \\
\text { Error } \\
\text { Mean }\end{array}$} & \multicolumn{2}{|c|}{$\begin{array}{l}95 \% \text { Confidence } \\
\text { Interval of the } \\
\text { Difference }\end{array}$} & & & \\
\hline & & & & Lower & Upper & & & \\
\hline $\begin{array}{l}\text { Kont- } \\
\text { HB_Konvensional } \\
\text { Eksp-HB_MM-PBL }\end{array}$ & -19.619 & 5.438 & 1.186 & -22.094 & $\overline{17.143}$ & $\overline{16.53}$ & 20 & .000 \\
\hline
\end{tabular}

Sources: Data Processed

When viewed from the difference in learning outcomes, the t-test score was -16.533 with a sig of 0.000 . This means that at $95 \%$ confidence level shows that there is a positive influence on the use of Mind Mapping and Problem Based Learning learning methods on student learning outcomes convincingly, or in other words the better expectations of Mind Mapping and Problem Based Learning learning methods by lecturers will have an impact on the higher results student learning. This supports the results of (Aisyaturrahmi, 2016) and (Adilah, 2017) that there are differences in student learning outcomes between the experimental class using the mind map learning method and the control class using the lecture method, where the experimental class learning outcomes are higher compared to the control class. 
427 Learning Methods Of Consilidated Statement in Advanced Accounting - Asepma Hygi Prihastuti, Sonia Sischa Eka Putri, Saipul Al Sukri

DOI: https://doi.org/10.31004/edukatif.v3i2.303

\section{CONCLUSIONS}

This research is based on the difficulty of students of the D3 Accounting STIE Persada Bunda program in understanding the concept of interrelationship between the sub-chapters of the consolidated financial statement material in advanced financial accounting courses, which results in low motivation and student learning outcomes. This might also be caused by the lecturer learning method which still uses conventional methods. This study aims to analyze the influence of the use of Mind Mapping and Problem Based Learning methods on motivation and learning outcomes of D3 Accounting STIE Persada Bunda students.

From the results of the analysis of different tests of learning motivation using t-tests obtained $t$ values of $-14,692$ with sig $=0,000$. With a sig of $0,000<0.05$ (tolerance of $5 \%$ ), it means that the use of Mind Mapping and Problem Based Learning learning methods has a positive influence on student motivation in a convincing way or in other words the use of Mind Mapping Method and Problem Based Learning has an influence on learning motivation better students than using conventional methods.

Then viewed from the difference in learning outcomes, the t-test score is -16.533 with a sig of 0.000 . This means that at $95 \%$ confidence level shows that there is a positive influence on the use of Mind Mapping and Problem Based Learning learning methods on student learning outcomes convincingly, or in other words the better application of Mind Mapping and Problem Based Learning methods by lecturers will have an impact on the higher results student learning.

\section{REFERENCES}

' A. (2016). CASES BASED LEARNING DAN DIRECT INSTRUCTION UNTUK MENINGKATKAN KEAKTIFAN SERTA HASIL BELAJAR STUDI PADA MAHASISWA MATA KULIAH AKUNTANSI KEUANGAN LANJUTAN. An-Nisbah: Jurnal Ekonomi Syariah. https://doi.org/10.21274/an.2016.2.2.127-144

Adilah, N. (2017). Indonesian Journal of Primary Education Motivasi dan Hasil Belajar Siswa. 1(1), 87-97.

Azrai, E. P., \& Refirman. (2013). Efektifitas Penerapan E- book sebagai Sumber Belajar Mandiri dalam Pembelajaran Biologi. Semirata FMIPA Universitas Lampung.

Bennett, N., \& Bloom, B. S. (1979). Human Characteristics and School Learning. British Journal of Educational Studies. https://doi.org/10.2307/3119887

Delors, J. (2013). The treasure within: Learning to know, learning to do, learning to live together and learning to be. What is the value of that treasure 15 years after its publication? International Review of Education. https://doi.org/10.1007/s11159-013-9350-8

Ferliyati, L., Kurniati, T. H., \& Suryanda, A. (2014). Penggunaan Multimedia Interaktif Berbasis Inkuiri dalam Meminimalisasi Miskonsepsi Siswa pada Materi Bioteknologi. Biosfer: Jurnal Pendidikan Biologi.

Herliani, R., \& Sibarani, C. G. G. (2017). PENERAPAN MODEL PEMBELAJARAN PROBLEM BASED LEARNING (PBL) BERBASIS BLENDED LEARNING UNTUK MENINGKATKAN MOTIVASI DAN HASIL BELAJAR AKUNTANSI. Jurnal Teknologi Pendidikan (JTP). https://doi.org/10.24114/jtp.v10i2.8732

Ideas for $21 \mathrm{st}$ Century Education. (2017). In Ideas for 21 st Century Education. https://doi.org/10.1201/9781315166575

Komala, R., Suryanda, A., \& Lismana, D. D. (2018). PENGEMBANGAN PALUDARIUM SEBAGAI MEDIA PEMBELAJARAN BIOLOGI POKOK BAHASAN EKOSISTEM DI SMA. BIOSFER: JURNAL PENDIDIKAN BIOLOGI. https://doi.org/10.21009/biosferjpb.9-1.2 
428 Learning Methods Of Consilidated Statement in Advanced Accounting - Asepma Hygi Prihastuti, Sonia Sischa Eka Putri, Saipul Al Sukri

DOI: https://doi.org/10.31004/edukatif.v3i2.303

Parasamya, C. E., \& Wahyuni, A. (2017). Upaya peningkatan hasil belajar fisika siswa melalui penerapan model pembelajaran problem based learning (pbl). Jurnal Ilmiah Mahasiswa (JIM) Pendidikan Fisika.

Sari, D. P. (2020). CHALLENGE OF LEARNING ENGLISH FROM REVOLUTION AS 21st CENTURY LEARNING FOR COMMUNITIES 5.0. ACITYA Journal of Teaching \& Education. https://doi.org/10.30650/ajte.v2i1.280

Suryanda, A., Sartono, N., \& Sa'Diyah, H. (2019). Developing smartphone-based laboratory manual as a learning media. Journal of Physics: Conference Series. https://doi.org/10.1088/17426596/1402/7/077077

Suryanda, Ade, Putri Azrai, E., \& Julita, A. (2019). Validasi Ahli pada Pengembangan Buku Saku Biologi Berbasis Mind Map (BIOMAP). BIODIK. https://doi.org/10.22437/bio.v5i3.6879

Suryanda, Ade, Rusdi, R., \& Kusumawati, D. (2018). PENGEMBANGAN PRAKTIKUM VIRTUAL URINALISIS SEBAGAI MEDIA PEMBELAJARAN BIOLOGI SISWA SMA KELAS XI. BIOSFER: JURNAL PENDIDIKAN BIOLOGI. https://doi.org/10.21009/biosferjpb.10-1.1

Syahidah, N. (2015). Metode Pembelajaran Mind Mapping Sebagai Upayah Mengembangkan Kreativitas Siswa dalam Pembelajaran Ekonomi. Prosiding Seminar Nasional. 